\title{
Modulating the Depth of Scrutiny in Judicial Review: Scope, Grounds, Intensity, Context
}

\author{
DEAN R KNIGHT*
}

This article focuses on the manner by which the courts modulate the depth of scrutiny in judicial review. Building on previous work that demonstrates that (overt and covert) variability is ubiquitous in judicial review, this article frames and explains the key methods employed to modulate the depth of scrutiny in New Zealand. The key methods are located within the broader Anglo-Commonwealth experience and are explicated in terms of four schemata drawn from the changing language and structure of successive editions of de Smith's distinguished textbook: scope of review, grounds of review, intensity of review and contextual review. A set of criteria for evaluating the virtues of the different schemata is then proposed, based on Fuller's principles of legality.

\section{Introduction}

One of the key features of the system of judicial review is the variation of the depth of scrutiny by the supervising court when examining administrative decisions made by ministers, officials, and public bodies. The circumstances of different cases lead to the court placing different emphases on the competing notions of judicial vigilance and restraint and, thus, the depth of scrutiny differs. ${ }^{1}$

\footnotetext{
* Senior Lecturer, Faculty of Law; Co-Director, New Zealand Centre for Public Law; Victoria University of Wellington (dean.knight@vuw.ac.nz). Thanks, subject to the usual caveat, to Eddie Clark, Bruce Harris, Marcelo Rodriguez Ferrere and Hanna Wilberg for comments on draft versions of this article. Thanks also to Alex Ladyman for research assistance.
} 
New Zealand's attitude towards this modulation of the depth of scrutiny is somewhat ambivalent, as I have previously outlined. ${ }^{2}$ On the one hand, there is strong scepticism, particularly amongst the senior judiciary, about the rise in the language of variability and attempts to give this modulation process independent or explicit doctrinal form. On the other hand, a close study suggests variation of the depth of scrutiny is deeply embedded in the jurisprudence and there are numerous judicial methodologies which covertly realise this modulation process. The broader Anglo-Commonwealth context also reveals similar diversity; the variation of the depth of scrutiny is ubiquitous but the manner in which the balance between vigilance and restraint is struck varies across time and across jurisdictions. ${ }^{3}$

The purpose of this article is relatively modest. First, I aim to frame and explain the key approaches employed to modulate the depth of scrutiny in New Zealand and to locate those approaches within the broader AngloCommonwealth context and traditions. Secondly, I identify and justify a set of criteria which we might adopt to evaluate the efficacy of the different approaches. The ultimate aim is to evaluate the virtues of each approach so that we can make an informed assessment of the efficacy of each. It is important that we move past disputes about the fact of variability and avoid our conversations about intensity being bogged down in the jargon of variability. In order to realise that goal, however, it is first necessary to synthesise the main different approaches used to modulate the depth of scrutiny and to develop the principles against which each are to be measured. It is these two aspects that this article addresses. The detailed normative assessment of the different approaches is beyond the scope of this article and is left for another day.

Taking cues from the language and structure of the leading textbook on judicial review, de Smith's Judicial Review, ${ }^{4}$ we can frame a number

1 For the adopted language of "vigilance" and "restraint" see Michael Fordham "Surveying the Grounds: Key Themes in Judicial Intervention" in Peter Leyland and Terry Woods (eds) Administrative Law Facing the Future: Old Constraints and New Horizons (Blackstone Press, London, 1997) ["Grounds"] 184 at 185-188; Michael Fordham Judicial Review Handbook (5th ed, Hart, Portland, 2008) [Handbook] at [P12], [P13].

2 Dean R Knight "Mapping the Rainbow of Review: Recognising Variable Intensity" [2010] NZ L Rev 393.

3 This article forms part of a broader project exploring the modulation of the depth of scrutiny in Anglo-Commonwealth administrative law. See Dean R Knight "Vigilance and Restraint in the Common Law of Judicial Review: Scope, Grounds, Intensity, Context" (PhD Thesis, London School of Economics and Political Science, 2015; forthcoming 2017, Cambridge University Press, Cambridge).

4 De Smith Judicial Review of Administrative Action (1st \& 2nd ed, Stevens, London, 1959 \& 1968); de Smith Judicial Review of Administrative Action (3rd ed, Stevens \& Sons, London, 1973); JM Evans de Smith's Judicial Review of Administrative Action (4th 
of distinct schemata employed throughout New Zealand and the AngloCommonwealth to organise the modulation of the depth of scrutiny:

(a) scope of review: based on an array of formalistic categories which determine whether judicial intervention is permissible;

(b) grounds of review: based on a simplified and generalised set of grounds of intervention, with implicit and different depths of review;

(c) intensity of review: based on the explicit calibration of the depth of scrutiny taking into account a series of constitutional, institutional and functional factors; and

(d) contextual review: based on an unstructured overall judgement about whether to intervene according to the circumstances of the case.

In this article, I introduce the schemata and explain their basic features. In particular, I identify their currency in New Zealand administrative law and link them to similar methodologies elsewhere in the Anglo-Commonwealth. ${ }^{5}$ In general terms, New Zealand's administrative law has - for decades centred on a simplified and generalised tripartite set of grounds of review. This followed a period where the approach in New Zealand echoed the formalistic scope of review schema that historically dominated Englishstyle judicial review. Recently, the rise of more intensive and circumstantial supervision has seen pressures to recognise different approaches, particularly the intensity of review and contextual review schemata. Thus, each of the schemata has some presence within New Zealand's system of judicial review, albeit the grounds of review schema continues to be most prevalent.

I then explore how we might go about assessing the efficacy of the schemata. For this, I suggest using Fuller's principles of legality on the basis that the different schemata are effectively rule-regimes that regulate the exercise of power and discretion by judges in their supervisory jurisdiction. ${ }^{6}$ Fuller identified eight rule of law-based criteria: generality, public accessibility, prospectivity, clarity, stability, non-contradiction, nonimpossibility and congruence. To that I have added one further criterion, hortatory versatility, to also recognise the wider functions of judicial review

ed, Stevens \& Sons, London, 1980); Lord Woolf and Jeffrey Jowell de Smith, Woolf \& Jowell - Judicial Review of Administrative Action (5th ed, Sweet \& Maxwell, London, 1995); Lord Woolf, Jeffrey Jowell, Andrew Le Sueur and others de Smith's Judicial Review (6th \& 7th ed, Sweet \& Maxwell, London, 2007 \& 2013). The textbook will be referred to here as "de Smith", along with the appropriate edition number.

5 The schemata present more distinctive and refined models for analysis than my earlier, more tentative, efforts to capture different approaches to variability: see Knight, above $\mathrm{n} 2$, at $430-431$.

6 Lon L Fuller The Morality of Law (revised ed, Yale University Press, New Haven, 1964). 
in administrative law. Using this set of criteria as an analytical tool allows us to isolate the strengths and weaknesses of the different schemata and to identify the various compromises each involves. I explain and justify these criteria as well as providing some flavour about how we can employ them to assess the virtues of different schemata.

\section{Framing Schemata for Mediating Vigilance and Restraint}

One useful way to capture the key schemata is to turn to de Smith's distinguished textbook, Judicial Review of Administrative Action, now known as de Smith's Judicial Review. ${ }^{7}$ De Smith's textbook provides a series of cues about the nature of the system of judicial review it expounds. In particular, the changing structure and key organising principles can help frame different schemata and draw out the approaches employed to modulate the depth of scrutiny within the Anglo-Commonwealth family of jurisdictions. ${ }^{8}$ Those cues then help to locate the New Zealand experience within its broader context. ${ }^{9}$

Over its seven editions, the nomenclature adopted in de Smith's textbook to describe the nature and circumstances of judicial intervention has changed over time: from scope of review to grounds of review to - perhaps, at least formatively - intensity of review. Hinted at, but not yet prominently recognised, is the language of contextual or instinctive review. The change in nomenclature, I argue, is not merely linguistic. The evolution in the denomination of judicial intervention speaks to change in the underlying style of review. The organisational transition - from scope to grounds to intensity, along with some limited recognition of open-textured context -

7 De Smith, above $\mathrm{n} 4$. The textbook is widely regarded as one of the most distinguished textbooks on judicial review in the Anglo-Commonwealth. See, for example, O Hood Phillips (1960) 23 MLR 458 (book review); JAG Griffith (1960) 18 CLJ 228 (book review); Louis L Jaffe (1961) 74 Harv LR 636 (book review); G Ganz (1969) 32 MLR 116 (book review); DGT Williams (1974) 33 CLJ 324 (book review); Carol Harlow "Politics and Principles: Some Rival Theories of Administrative Law" (1981) 44 MLR 113; DJ Galligan "Judicial Review and the Textbook Writers" (1982) 2 OJLS 257; Cosmo Graham (1997) 3 EPL 149 (book review); Patrick Birkinshaw (2009) 15 EPL 279 (book review); Sir John Laws [1996] JR 49 (book review); Fordham Handbook, above $n$, at [11.2.3].

8 On the familial association and comparative tradition, see, for example: Cheryl Saunders, "Apples, Oranges and Comparative Administrative Law" [2006] AJ 423 at 427; Robin Cooke Turning Points of the Common Law (Sweet \& Maxwell, London, 1997) at 2; Michael Taggart “A Australian Exceptionalism' in Judicial Review” (2008) 36 FLR 1.

9 The use of de Smith's textbook to frame the different schemata means the discussion of English jurisprudence is more prominent than other jurisdictions. 
points to a move away from legal formalism and categorical approaches and towards more open-textured and explicitly circumstantial approaches. The various schemata represent different ways to organise and execute the supervisory task. And, importantly, the schemata capture different ways to mediate the balance between restraint and vigilance. Each schema provides distinct ways to modulate the depth of scrutiny to take account of context and the limitations of judicial supervision.

We can treat these as key schemata for enabling the modulation of depth of review. Some care needs to be taken in relation to the definition of these schemata, however. They are constructed in order to capture the dominant methodologies operating in systems of judicial review at different times and in different places. They are necessarily generalised précis, limited in the extent to which they can capture the vast and nuanced doctrines existing at any point in time. Inevitably, there is some overlap between the given schemata and instances where underlying doctrines could plausibly be categorised under multiple schemata. The key concern, though, is the dominant style and the nature of the methods that are foregrounded in the judicial analysis.

\section{A Scope of review}

Scope of review is based on categorical distinctions and formalistic reasoning: ${ }^{10}$

Formalism is formal in that it requires judges to operate with categories and distinctions that determine results without the judges having to deploy substantive arguments that underpin the categories and distinctions.

The depth of scrutiny is modulated indirectly, by the classification of a decision or function into a category that determines whether it is capable of being reviewed or not. Multifarious, often complexly drawn, categories are the main feature of the doctrinal landscape.

The language of "scope of review" is employed frequently in de Smith's textbook through the first four editions (1959-1980) to showcase the analysis of the circumstances of judicial intervention. ${ }^{11}$ De Smith did not incorporate an explicit organising device for the analysis; the striking feature of the book is the vast morass of case law it incorporates. Vires and jurisdiction are loose themes evident throughout the text, but the language of scope of

10 David Dyzenhaus “Constituting the Rule of Law” (2002) 27 Queen's LJ 445 at 450.

11 De Smith, above n 4, (1st ed) at 15; (2nd ed) at 22; (3rd ed) at 23; (4th ed) at 27. The fourth edition was updated by John Evans, following de Smith's death in 1974. 
review is a significant feature. This reflected the formalistic and deferential supervision that was the then dominant approach in judicial review in England and elsewhere in the Anglo-Commonwealth jurisdictions. ${ }^{12}$ The judicial method then had a technical and formalistic character where the courts' ability to intervene was conditioned according to rigid categories of analysis. Harlow labels this the "classic model" of judicial review. ${ }^{13}$ Judicial review doctrine was rigid and circumspect. "The grounds for review were restricted", Harlow explains, "and a strict interpretation of the doctrine of precedent inhibited rapid changes of direction". ${ }^{14}$ Judicial method - and thus the depth of review - was conditioned by critical distinctions, such as jurisdictional-non-jurisdictional, law-fact-policy, process-substance, and judicial-administrative-legislative.

The approach was also the prevailing style of English — and, thus, New Zealand - judicial review at the opening point of this study when de Smith penned his first edition. Judicial restraint characterised the early and middle parts of the 20th century. ${ }^{15}$ The supervisory jurisdiction began to be reinvigorated in the 1960 s, with a "trilogy of great cases" — Ridge $v$

12 Sian Elias "Righting Administrative Law" in David Dyzenhaus, Murray Hunt and Grant Huscroft (eds) A Simple Common Lawyer: Essays in Honour of Michael Taggart (Hart, Oxford, 2009) 55 at 57 (NZ); Philip A Joseph "The Contribution of the Court of Appeal to Commonwealth Administrative Law" in Rick Bigwood (ed) The Permanent New Zealand Court of Appeal (Hart, Oxford, 2009) 41 (NZ); Michael Taggart "The New Zealandness of New Zealand Public Law" (2004) 15 PLR 81 (NZ); PW Hogg "The Supreme Court of Canada and Administrative Law, 1949-1971" (1973) 11 Osgoode LJ 187 (Canada); Audrey Macklin “Standard of Review: Back to the Future?" in Colleen M Flood and Lorne Sossin (eds) Administrative Law in Context (2nd ed, Emond Montgomery, Toronto, 2013) 279 (Canada); Michael Taggart "Prolegomenon to an Intellectual History of Administrative Law in the Twentieth Century: The Case of John Willis and Canadian Administrative Law" (2005) 43 Osgoode Hall LJ 223 at 224 (Canada); Peter Cane and Leighton McDonald Principles of Adminstrative Law: Legal Regulation of Governance (2nd ed, Oxford University Press, Oxford, 2012) at 15 (Australia).

13 Carol Harlow "A Special Relationship? American Influences on Judicial Review in England" in Ian Loveland (ed) A Special Relationship? American Influences on Public Law in the UK (Clarendon, Oxford, 1995) 79 at 83. See also Michael Taggart "Reinventing Administrative Law" in Nicholas Bamforth and Peter Leyland (eds) Public Law in a Multi-Layered Constitution (Hart, Oxford, 2003) 311 at 312; and Richard Rawlings "Modelling Judicial Review" (2008) 61 CLP 95 at 98.

14 Harlow, above n 13 , at 83 .

15 Harlow, above n 13, at 83; Michael Taggart "Proportionality, Deference, Wednesbury" [2008] NZ L Rev 423 at 429; Rodney Austin "Administrative Law's Reaction to the Changing Concepts of Public Service" in Peter Leyland and Terry Woods (eds) Administrative Law Facing the Future (Blackstone Press, London, 1997) at 30. 
Baldwin, ${ }^{16}$ Anisminic, ${ }^{17}$ and Padfield ${ }^{18}$ — marking a transition into what has been described as a "new activist era". ${ }^{19}$ The judicial reinvigoration enlarged the ambit of some of the categories which were subjected to judicial scrutiny and made some particular distinctions obsolete. But it did not repudiate the essential style of legal analysis: depth of scrutiny - expressed in binary terms - continued to be set indirectly through a process of categorisation.

The approach continues to dominate Australian administrative law today, ${ }^{20}$ but has otherwise fallen out of favour in New Zealand and elsewhere in the Anglo-Commonwealth. It has been overtaken by less formalistic approaches to the depth of review and is now only of historic interest. But it remains useful in charting the general trajectory of administrative law in New Zealand.

\section{B Grounds of review}

The prevailing approach in New Zealand nowadays is the organisation of the circumstances of judicial intervention around a few generalised grounds of review, echoing the approach of its parent jurisdiction, England. The systemisation of judicial review doctrine in this way was famously heralded by Lord Diplock in his seminal speech in Council of Civil Service Unions $(C C S U)$; as is well known, three grounds were ordained - illegality,

16 Ridge v Baldwin [1964] AC 40 (HL).

17 Anisminic Ltd v Foreign Compensation Commission [1969] 2 AC 147 (HL).

18 Padfield v Minister of Agriculture, Fisheries and Food [1968] AC 997 (HL).

19 Harlow, above n 13, at 84, 87. See also William Wade and Christopher Forsyth Administrative Law (11th ed, Oxford University Press, Oxford, 2014) at 12; and Carol Harlow and Richard Rawlings Law and Administration (3rd ed, Cambridge University Press, Cambridge, 2009) 100-102.

20 See generally Peter Cane "The Making of Australian Administrative Law" (2003) 24 Australian Bar Review 114 at 133; Taggart, above n 8; Anthony Mason "Mike Taggart and Australian Exceptionalism" in David Dyzenhaus, Murray Hunt and Grant Huscroft (eds) A Simple Common Lawyer: Essays in Honour of Michael Taggart (Hart, Oxford, 2009) 179; Mark Aronson "Process, Quality, and Variable Standards: Responding to an Agent Provocateur" in David Dyzenhaus, Murray Hunt and Grant Huscroft (eds) A Simple Common Lawyer: Essays in Honour of Michael Taggart (Hart, Oxford, 2009) 5; Thomas Poole "Between the Devil and the Deep Blue Sea" in Linda Pearson, Carol Harlow and Michael Taggart (eds) Administrative Law in a Changing State (Hart, Oxford, 2008) 15 at 42; Alan Freckelton "The Concept of Deference in Judicial Review of Administrative Decisions in Australia - Part 1" (2013) 73 AIAL Forum at 52. 
procedural impropriety and irrationality - with the potential for further grounds to be added. ${ }^{21}$

Fordham captures the essence of the grounds of review schema: ${ }^{22}$

The grounds for judicial review are court-recognised rules of good administration: the judges' way of explaining when a public authority has overstepped the mark and when judicial intervention is warranted. They reflect a careful balance between appropriate vigilance and appropriate restraint.

The expression of standards form a "framework" for judicial analysis but also permit "flexibility of response". ${ }^{23}$ The grounds are designed to capture, in systematic and simplified form, the circumstances in which the courts are prepared to intervene. This schema continues the indirect and categorical approach to the determination of the depth of scrutiny but with a different emphasis. The depth of review is captured by a handful of grounds, expressed in a general way with a degree of abstraction. But, as with the scope of review approach, classification - in this case, based on which ground is engaged - dominates the mediation of the balance between vigilance and restraint. In some cases the grounds manifest a depth of scrutiny which is strict; in others it is deferential.

Lord Diplock's grounds were adopted as the organising framework for much of the fifth and later editions of de Smith (from 1995); ${ }^{24}$ the language of "grounds of review" overtook "scope of review" and the tripartite grounds of review were conscripted as chapter headings. ${ }^{25}$ Lord Diplock's statement of grounds assumed a certain cachet in English administrative law. ${ }^{26}$ As Forsyth

21 Council of Civil Service Unions v Minister for the Civil Service [1985] AC 374 (HL) [CCSU].

22 Fordham "Grounds", above n 1, at 199.

23 At 199.

24 De Smith, above $\mathrm{n} 4$.

25 De Smith, above n 4, (5th ed) at ix. Lord Diplock's grounds of review were said to provide "a useful structure to help delineate the bounds of the unlawful decision". For example, in the 5th edition, five chapters were devoted to "procedural fairness" (chs 8-12) and one each to "illegality" (ch 7) and the "unreasonable exercise of power" (ch 13). The suitability of the grounds of review for "chapter headings" had been noted some years before by Lord Donaldson: see $R v$ Secretary of State for the Home Department, ex parte Brind [1991] 1 AC 696 at 722 (HL) — cited in de Smith, above n 4, (5th ed) at [III-003], n 3.

26 The grounds were endorsed and adopted as a doctrinal framework in numerous cases, including at the highest level in Brind, above n 25; Wheeler v Leicester City Council [1985] AC 1054 (HL); Boddington v British Transport Police [1999] 2 AC 143 (HL); 
observes, the threefold formula "immediately went canonical" ${ }^{27}$ Years after their exposition, Fordham argues the tripartite classification appears "largely intact" (despite other significant change in public law) and "remains the most helpful outline", even if some "trendier" labels have continued to emerge. ${ }^{28}$

The tripartite expression of grounds of review has a strong foothold in New Zealand administrative law, although the prevailing nomenclature is a simplified version of Lord Diplock's recitation in CCSU. Contemporaneous with the systemisation of the grounds in $C C S U$, Lord Cooke propounded a similar tripartite statement of grounds of review: ${ }^{29}$

[T]he substantive principles of judicial review are simply that the decisionmaker must act in accordance with law, fairly and reasonably.

This threefold classification mimics Lord Diplock's categorisation; ${ }^{30}$ the difference lies in their simplified language and expression as positive norms or standards to be complied with by administrators. Lord Cooke confirmed his extra-judicial statement of the grounds in a number of judicial decisions. ${ }^{31}$ As with Lord Diplock's statement, cautionary comments about potential overlap and merger are also prominent. ${ }^{32}$

The tripartite identification of the grounds of review has also been repeated and endorsed in numerous other New Zealand cases (expressed in

and $R v$ Secretary of State for the Environment, ex parte Nottinghamshire City Council [1986] AC 240 (HL) ("valuable, and already "classical"').

27 Christopher F Forsyth "Council of Civil Service Unions v Minister of Civil Service (1985)" in Peter Cane and Joanne Conaghan (eds) The New Oxford Companion to Law (Oxford University Press, Oxford, 2008) at 245.

28 Fordham "Grounds", above n 1, at 185 (notably, "want of due process" for procedural impropriety and "abuse of power" for irrationality).

29 Robin Cooke "The Struggle for Simplicity in Administrative Law" in Michael Taggart (ed) Judicial Review of Administrative Action in the 1980s - Problems and Prospects (Oxford University Press, Auckland, 1986) 1 at 5.

30 Cooke, above n 29, at 6: referring to "Third Thoughts on Administrative Law" [1979] NZ Recent Law 218 at 225.

31 New Zealand Fishing Industry Assoc Inc v Minister of Agriculture and Fisheries [1988] 1 NZLR 544 (CA) at 552. See also Minister of Energy v Petrocorp Exploration Ltd [1989] 1 NZLR 348 at 352; Jenssen v Director-General of Agriculture and Fisheries CA313/91, 16 September 1992 at 3.

32 See, for example, NZ Fishing Industry, above n 31. See generally also Matthew Smith The New Zealand Judicial Review Handbook (Brookers, Wellington, 2011) at [4.2]. 
the same way as Lord Cooke, ${ }^{33}$ Lord Diplock, ${ }^{34}$ or something analogous). ${ }^{35}$ In addition, a number of judges have adopted similar but marginally different formulations of the grounds of review. ${ }^{36}$ As an example, one High Court judge recently recorded that the recognised grounds of review "remain firmly those stated by Lord Diplock in CCSU" and also "are captured in [Lord Cooke's] wonderfully succinct statement in NZ Fishing". ${ }^{37}$ This tripartite expression of the grounds is also recognised as the prevailing orthodoxy in textbooks and practice guides. ${ }^{38}$

33 See, for example, Peters v Davison [1999] 2 NZLR 164 (CA) at 208; BNZ Investments Ltd v Commissioner of Inland Revenue [2007] NZCA 356, [2008] 1 NZLR 598, [15]; Osbourne v Chief Executive of the Ministry of Social Development [2010] 1 NZLR 559 (HC) at [54]. See also Smith, above n 32, at [4.1.2].

34 See, for example, University of Auckland v International Education Appeal Authority (No 1) [2010] NZAR 1 (HC) at [35]; Adlam v Stratford Racing Club Inc [2007] NZAR 543 (HC); NZI Financial Corporation Ltd v NZ Kiwifruit Authority [1986] 1 NZLR 159 (HC) at 172. See also Smith, above n 32, at [4.1.3].

35 See, for example, Pring v Wanganui District Council [1999] NZRMA 519 (CA) at [7]; Official Assignee v Chief Executive of Ministry of Fisheries [2002] 2 NZLR 222 (CA) at [85]; Brierley Investments Ltd v Bouzaid [1993] 3 NZLR 655 (CA) at 660-661. See also Smith, above n 32, at [4.1.4] and [4.1.5].

36 See, for example, Keith J in Peters v Davison, above n 33, at 180-181 (Lord Templeman's language from $R v$ Inland Revenue Commissioners ex p Preston [1985] AC 385 (HL)); Richardson J in Mackenzie District Council v Electricity Corporation of New Zealand [1992] 3 NZLR 41 (CA) at 43 and in Wellington City Council v Woolworths New Zealand Ltd (No 2) [1996] 2 NZLR 537 (CA) [Woolworths] at 545 (adoption of the shorthand of "familiar Wednesbury grounds", which echo the tripartite formulations of Lord Diplock and Lord Cooke); Sian Elias "National Lecture on Administrative Law" (AIAL conference, Canberra, ACT, 18 July 2013) at 9 (speaking extra-judicially of overarching requirements of "reasonableness, fairness, [and] legality", to which she also added "consistency, and equal treatment").

37 Powerco v Commerce Commission HC Wellington CIV-2005-485-1066, 9 June 2006 [Powerco] at [21]. The question arose in the context of whether proportionality was a recognised ground of review, which Wild $\mathrm{J}$ held it was not.

38 Philip A Joseph Constitutional and Administrative Law in New Zealand (4th ed, Brookers, Wellington, 2014) at 854 and chs 23-25 ("principal grounds of review", adopting each as chapter headings for his detailed exposition); Graham Taylor Judicial Review: A New Zealand Perspective (3rd ed, LexisNexis, Wellington, 2014) at [11.01] ("conventional" and "the 'firmly' recognised current description" of New Zealand's grounds of review; adopting, however, a different framework for his exposition); Smith, above n 32, at [4.1] (recognising the threefold summary formulations, but later also identifying "twenty-six separate but overlapping" individual grounds of review); The Laws of New Zealand, Administrative Law, at [6] ("Major grounds of review"); Crown Law Office A Judge Over Your Shoulder (Crown Law, Wellington, 2005) at [14] ("The grounds of challenge can be broadly divided into: illegality (acting outside the scope of the power; getting the law wrong); unfairness (sometimes referred to as procedural 
Despite being well established, one senior judge strongly criticised this framework in a notable appraisal of judicial review in New Zealand. Justice Hammond, in his separate concurring judgment in Lab Tests, argued that the doctrinal grounds of review are complicit in causing confusion about the circumstances in which the courts will intervene: ${ }^{39}$

[W] hen fundamental disputes about "purpose" are leavened with confusion as to the principles on which courts will intervene (often called the "grounds for review"), the state of the law is rendered distinctly problematic.

Doubting judicial efforts to formulate "a unified theory of judicial review", ${ }^{40}$ he said "grand theorem approaches fail to drill down far enough to enable respectable advice to be given to parties who are supposed to abide by the law". ${ }^{41}$ Further, he pointed to the lack of an agreed schematic: ${ }^{42}$

As far as the grounds of review are concerned, the difficulty stems partly from the lack of an agreed classification or taxonomy, accompanied by properly developed substantive principles as to when a court will intervene by way of judicial review, particularly in "merits" cases.

However, his alternative ("functional rather than doctrinal") approach to judicial review — proposed tentatively — in many respects reprises the current threefold statement. ${ }^{43}$ And there seems little appetite in New Zealand for such a revision of the organising principles of judicial review.

impropriety); unreasonableness."); Geoffrey Palmer and Matthew Palmer Bridled Power (4th ed, Oxford University Press, Oxford, 2004) at 292-295 (identifying illegality, breach of the rules of natural justice, irrationality or unreasonableness, along with legitimate expectations).

39 Lab Tests Auckland Ltd v Auckland District Health Board [2008] NZCA 385, [2009] 1 NZLR 776 (CA) [Lab Tests] at [370]. Leave for appeal was, oddly, declined in Diagnostic Medlab Ltd v Auckland District Health Board [2009] NZSC 10, (2009) 19 PRNZ 217 ("ultimately turns on its own facts" and no "arguable question of public or general importance").

40 At [374].

41 At [378]. Notably, he dismissed "spectrums of response" or "deference" as "quite unhelpful, and even unworkable": at [379].

42 At [380].

43 At [381]-[384]. Hammond J suggested the grounds of review be grouped according to procedural grounds of review ("the conduct of the decision-maker and include procedural fairness requirements, fair hearing rules, and rules against bias"); the decisionmaker's reasoning processes ("things like misappreciation of the law; unauthorised delegation; and the perennial problem of control of the exercise of a discretion"); and grounds relating to the decision itself, not the procedures adopted or reasoning process 
In summary, like its English parent, New Zealand's jurisprudence is generally structured around well-entrenched grounds of review, expressed in tripartite form. As identified earlier, this schema brings a categorical approach to the mediation of the balance between vigilance and restraint, where the modulation of the depth of scrutiny takes place indirectly. The depth of scrutiny is modulated in four key ways: ${ }^{44}$ classification, evolution, reformulation and circumscription.

First, different depths of review apply based on the selection of the applicable ground of review, through a process of classification. The grounds of review tend to overlap and the distinctions on which these grounds depend are prone to break down. ${ }^{45}$ For example, an alleged error may be classified as one of either law or fact, enabling different depth of review. ${ }^{46}$ If the error is one of law, then the court can express its own view on whether the decision is correct; if it is a factual error, the deferential Wednesbury standard of unreasonableness would ordinarily apply. ${ }^{47}$ The boundary between law and discretion is similarly vexed. ${ }^{48}$ For example, the principle of legality has the effect of moving questions of compliance with higher-order norms (such as fundamental human rights or international law treaty obligations)

("substantive grounds of review, even where a decision maker has assiduously followed all required procedures and has made no errors of reasoning"). But his taxonomy simply recreates groups which mimic the chapter divisions of Lord Diplock and Lord Cooke, albeit with new chapter headings: procedural grounds rather than procedural impropriety or fairly; reasoning process grounds rather than illegality or in accordance with law; and substantive or abuse of power grounds rather than irrationality or reasonably. Subtle differences may lie in the allocation of some specific grounds (for example, it is unclear where Hammond $\mathrm{J}$ sees relevancy principles being located; whether as reasoning or substantive grounds).

44 For extended analysis, see Knight, above n 2.

45 Michael Taggart “Administrative Law” [2006] NZ Law Rev 75 at 83.

46 Timothy Endicott "Questions of Law" (1998) 114 LQR 292; Paul Craig "Judicial Review, Appeal and Factual Error" [2004] PL 788; Rebecca Williams "When is an Error not an Error?" [2007] PL 793; HWR Wade “Anglo-American Administrative Law" (1966) 82 LQR 226.

47 Compare, for example, Hawkins v Minister of Justice [1991] 2 NZLR 530 (CA) (statutory precondition treated as raising matters of factual evaluation and subject only to reasonableness review) and Discount Brands Ltd v Westfield (New Zealand) Ltd [2005] NZSC 17, [2005] 2 NZLR 597 (statutory precondition treated as raising questions of legality and therefore subjected to close scrutiny).

48 See also, for example, Hanna Wilberg "Deference on Relevance and Purpose? Wrestling with the Law/Discretion Divide" in Hanna Wilberg and Mark Elliott (eds) The Scope and Intensity of Substantive Review (Hart, Oxford, 2015) at 263 (classification problems in relation to the principles of relevancy and purpose). 
from the realm of discretion to the realm of law; in doing so, the deferential Wednesbury standard is replaced with a strict lawfulness standard. ${ }^{49}$

Secondly, evolution generates different depths of scrutiny, as alternative grounds of review manifesting different degrees of intensity are recognised. When the grounds were encapsulated in their tripartite formulation, the door was also left open for other grounds of review to develop. ${ }^{50}$ These emergent grounds present different depths of scrutiny - usually more vigilant intensity - to the traditional tripartite grounds. As in England, ${ }^{51}$ some emergent grounds have crystallised in New Zealand, ${ }^{52}$ such as substantive

49 See, for example, Cropp v Judicial Committee [2008] NZSC 46, [2008] 3 NZLR 774 at [26]; Canterbury Regional Council v Independent Fisheries Ltd [2012] NZCA 601, [2013] 2 NZLR 57 at [140]; Claudia Geiringer "The Principle of Legality and the Bill of Rights Act: A Critical Examination of $R v$ Hansen" (2008) 6 NZJPIL 59; Taggart, above $\mathrm{n} 15$, at 431. On its particular currency in international law see Puli'uvea v Removal Review Authority [1996] 3 NZLR 538 (CA); Zaoui v Attorney-General (No 2) [2005] NZSC 38, [2006] 1 NZLR 289; Ye v Minister of Immigration [2009] NZSC 76, [2010] 1 NZLR 104. See also Claudia Geiringer "Tavita and All That" (2004) 21 NZULR 66; and Claudia Geiringer "International Law through the Lens of Zaoui: Where is New Zealand at?" (2006) 17 PLR 300. The presumption of consistency with international law operates more strongly in New Zealand than in England: see P Sales and J Clement "International Law in Domestic Courts: The Developing Framework" [2008] LQR 388 at 393.

$50 C C S U$, above $\mathrm{n} 21$, at 410.

51 Substantive legitimate expectation: $R$ (Coughlan) $v$ North and East Devon HA [2001] QB 213 (CA) [Coughlan], endorsed by the House of Lords in $R$ (Reprotech) $v$ East Sussex County Council [2002] UKHL 8, [2003] 1 WLR 348 at [34] and the Privy Council in Paponette v Attorney-General of Trinidad and Tobago [2012] UKPC 32, [2012] 1 AC 1 at [34]. Proportionality: accepted for reviewing penalties ( $R v$ Barnsley Metropolitan Borough Council, ex parte Hook [1976] 1 WLR 1052 (CA); R v St Albans Crown Court, ex parte Cinnamond [1981] QB 480) and for human rights adjudication (De Freitas $v$ Permanent Secretary of Ministry of Agriculture, Fisheries, Lands and Housing [1999] 1 AC 69 (PC); $R$ (Daly) v Secretary of State for the Home Department [2001] UKHL 26, [2001] 2 AC 532 [Daly]; Huang $v$ Secretary of State for the Home Office [2007] UKHL 11, [2007] 2 AC 167 [Huang]), but not yet adopted as a general ground of review ( $R$ (Association of British Civilian Internees: Far East Region) v Secretary of State for Defence [2003] EWCA Civ 473, [2003] QB 1397). Mistake of fact: E v Secretary of State for the Home Department [2004] EWCA Civ 49, [2004] QB 1044.

52 Other substantive grounds, such as unequal treatment (for example, Pharmaceutical Management Agency Ltd v Roussel Uclaf Australia Pty Ltd [1998] NZAR 58), substantive fairness (for example, Thames Valley Electric Power Board v NZFP Pulp \& Paper Ltd [1994] 2 NZLR 641 (CA) [Thames Valley]), and the innominate ground (for example, Electoral Commission v Cameron [1997] 2 NZLR 421 (CA) [Cameron]), have had limited success, despite some strong efforts to have them recognised. On the innominate ground see more generally "Contextual Review" below, where this ground more naturally fits. 
legitimate expectation, ${ }^{53}$ proportionality ${ }^{54}$ and mistake of fact, ${ }^{55}$ although their application remains narrow and restricted to particular circumstances. The recognition of potential development of other grounds of review brings other dimensions of variability to the judicial method. This variability is both immediate (where a ground has been recognised within the overall schema) and longer-term (where a ground is able to be explored as a prospective ground). Moreover, the emergent grounds tend not to have the universal application of the traditional tripartite grounds; in order to rely on them, narrow gateways or preconditions must first be satisfied. This adds another layer of classification, which further augments the variability associated with them.

Thirdly, the traditional grounds may be reformulated to express a different balance between vigilance and restraint. The most obvious example is the attempt to simplify and rationalise the irrationality or unreasonableness

53 Substantive legitimate expectation is recognised in principle but rarely made out and perhaps more diluted in intensity: Attorney-General $v$ Steelfort Engineering Co Ltd (1999) 1 NZCC 55-005 (CA); New Zealand Maori Council v Attorney-General (Broadcasting Assets) [1994] 1 AC 466 at 467 (PC); Challis v Destination Marlborough Trust Board Inc [2003] 2 NZLR 107 (HC); NZ Association for Migration and Investments Inc v Attorney-General [2006] NZAR 45 (HC); Comptroller of Customs v Terminals (NZ) Ltd (2012) 2 NZCC 55-040; GXL Royalties Ltd v Minister of Energy [2010] NZCA 185, [2010] NZAR 518; Hanna Wilberg “Administrative Law” [2010] NZ L Rev 177 at 207; Smith, above n 32, at [55.4].

54 There is reluctance to embrace proportionality as a universal ground of review (see, for example, Powerco, above n 37, at [14]-[15]; Wolf v Minister of Immigration [2004] NZAR 414 (HC)), but the courts have been prepared to intervene to address (excessive) disproportionality in penalties and sanctions (Institute of Chartered Accountants of New Zealand v Bevan [2003] 1 NZLR 154 (CA)), and proportionality is the accepted methodology for assessing whether government action abridging rights is justified and therefore lawful under the New Zealand Bill of Rights Act 1990 ( $R v$ Hansen [2007] NZSC 7, [2007] 3 NZLR 1; Moonen v Film and Literature Board of Review [2000] 2 NZLR 9 (CA)). The proportionality method is, however, less frequently deployed in administrative law cases raising human rights issues than the widespread endorsement attests: Claudia Geiringer "Sources of Resistance to Proportionality Review of Administrative Power under the New Zealand Bill of Rights Act" (2013) 11 NZJPIL 123.

55 This ground was notably seeded by Lord Cooke in Daganayasi v Minister of Immigration [1980] 2 NZLR 130 (CA) [Daganayasi]; while not since receiving general endorsement at the appellate level, this ground has been successfully relied on in a number of High Court decisions: Taiaroa v Minister of Justice HC Wellington CP 99/94, 4 October 1994 [Taiaroa]; Northern Inshore Fisheries Company Ltd v Minister of Fisheries HC Wellington CP 235/01, 4 March 2002; D v M and Board of Trustees of Auckland Grammar School [2003] NZAR 726 (HC); Air Nelson Ltd v Minister of Transport [2007] NZAR 266 (HC). See generally Hanna Wilberg "Substantive Grounds of Review: Mistake of Fact" (Legal Research Foundation conference, Auckland, 1 April 2011). 
ground. ${ }^{56}$ However, to date, these efforts have not been fruitful and the Wednesbury standard still provides the default test.

Finally, the ordinarily available grounds of review may be circumscribed. Access to the traditional grounds of review may be restricted through the application of the principle of non-justiciability ${ }^{57}$ In its strongest formulation, review may not be permitted at all — that is, none of the grounds of review is treated as being applicable. ${ }^{58} \mathrm{In}$ its softer formulation, the suite of grounds of review may be circumscribed or modified to take account of the context of particular cases. In doing so, greater weight is placed on judicial restraint and more deferential supervision results. Partial non-justiciability is seen particularly in the limited basis for reviewing prosecutorial decisions ${ }^{59}$ and commercial decisions of quasi-public bodies. ${ }^{60}$

\section{Intensity of review}

Intensity of review brings questions of the depth of scrutiny into the foreground. The hallmark of this style of review is the explicit calibration of the depth of scrutiny as a preliminary step in the supervisory process.

56 See particularly Lord Cooke's efforts in Cooke, above n 29, at 15; Robin Cooke "The Road Ahead for the Common Law" (2004) 53 ICLQ 273 at 275; $R v$ Chief Constable of Sussex, Ex parte International Traders 'Ferry Ltd [1999] 2 AC 418 at 452 (HL); Daly, above n 51, at 549. See also Thomas J in Waitakere City Council v Lovelock [1997] 2 NZLR 385 (CA) [Lovelock].

57 BV Harris "Judicial Review, Justiciability and the Prerogative of Mercy" (2003) 62 CLJ 631 (describing "primary" (absolute) and "secondary" (limited) non-justiciability); Rayner Thwaites "The Changing Landscape of Non-Justiciability” [2016] NZ L Rev 63.

58 See, for example, Curtis v Minister of Defence [2002] 2 NZLR 744 (CA) at [26]-[28] (question about whether disbanding of the air strike force left the air force insufficiently armed non-justiciable because the question was something that the government of the day should be held accountable for through political — not legal — processes). It is possible to frame non-justiciability in terms of explicit variable intensity; however the courts have been slow to connect this methodology with other developments in variable intensity and usually deploy it as a stand-alone doctrine. For the identification of the linkages see Taggart, above n 13, at 84; Andrew Le Sueur "The Rise and Ruin of Unreasonableness?" [2005] JR 32. King goes further and suggests the justiciability principle has now been overtaken by the notion of deference: Jeff A King "The Justiciability of Resource Allocation" (2007) 70 MLR 197 at 198.

59 Polynesian Spa Ltd v Osborne [2005] NZAR 408 (HC); Osborne v Worksafe New Zealand [2015] NZHC 2991.

60 Mercury Energy Ltd $v$ Electricity Corporation of New Zealand Ltd [1994] 2 NZLR 385 at 391 (only reviewable for "fraud, corruption or bad faith"). See also Lab Tests, above n 39; Air New Zealand Ltd v Wellington International Airport Ltd [2009] NZCA 259, [2009] 3 NZLR 713; Wilberg, above n 53. 
The essence of this approach has been described in terms of an explicit style of reasoning: ${ }^{61}$ "It is simply a means of structuring the discourse on deference." Openness in the reasoning and calibration process is prioritised, with conceptual considerations dominating.

The concept and language of "intensity of review" makes a brief cameo appearance in the de Smith's fifth edition, ${ }^{62}$ but gains a much stronger foothold in the sixth and seventh editions. In those editions, "intensity of review" gains significant prominence and is subjected to extensive analysis but the discussion of intensity of review still occurs within a general schema or framework of grounds of review. For example, intensity of review is afforded its own subsection in the rebranded chapter on "Substantive Review and Justification" (formerly described as "Unreasonable Exercise of Power"). ${ }^{63}$ Under the heading "Intensity of Review", the authors develop in some detail the role of latitude and uniformity in judicial review. ${ }^{64}$ Significantly, intensity is depicted in terms of a complete continuum of methods. A number of different formulations of variable intensity are identified, from "full intensity review" on the one hand, to non-justiciable decisions on the other. ${ }^{65}$ In between, "structured proportionality review" and "variable intensity unreasonableness review" (capturing separately "anxious scrutiny", "standard Wednesbury" and "light touch" forms of unreasonableness) are charted. ${ }^{66}$

In English-style judicial review, this judicial method tends to be seen in particular grounds or doctrines for substantive review, rather than providing a grand schematic. In particular, it arises from notions of "hard look", variegated forms of unreasonableness and structured forms of deference; all these doctrines exhibit the transparent mediation of the balance between

61 Grant Huscroft "Judicial Review from CUPE to CUPE" in Grant Huscroft and Michael Taggart (eds) Inside and Outside Canadian Administrative Law (University of Toronto Press, Toronto, 2006) 296 at 297.

62 De Smith, above n 4, (5th ed) at [6-035], [13-079]-[13-084].

63 De Smith, above n 4, (6th ed) at [11-085]-[11-102]; (7th ed) at [11-086]-[11-102].

64 Two questions are posed: "To what extent should the courts allow a degree of latitude or leeway to the decision-maker? And to what extent should it be uniform?": de Smith, above $\mathrm{n} 4,(6 \mathrm{th}$ ed) at [11-086]. While there is reference to uniformity, the commentary which follows makes it clear variability is embraced.

65 De Smith, above n 4, (6th ed) at [11-087]; (7th ed) at [11-087]. Full intensity, or correctness, review is described as arising in three main fields: (a) decisions made where no evidence exists to support it or an established fact is ignored; (b) decisions which offend the principle of consistency; and (c) some (but not all) decisions which undermine legitimate expectations.

66 De Smith, above n 4, (6th ed) at [11-092]; (7th ed) at [11-086], [11-092]-[11-097]. The authors say the default position - "at the time of writing" — is still the Wednesbury formulation of unreasonableness. 
vigilance and restraint, based on various constitutional, institutional and functional factors ${ }^{67}$ Elsewhere, the manifestation of intensity of review in its schematic form is seen vividly in Canada's framework of explicit standards of review, most prominently before its recent rationalisation. ${ }^{68}$ Under this more general framework, the depth of review was calibrated explicitly based on forms of reasonableness and correctness review, notably in relation to a wider range of questions than seen in the variable form of substantive review in England. While the different forms of unreasonableness have since been collapsed in Canada, the determination of the appropriate degree of judicial restraint continues to be the first step in the supervisory process. ${ }^{69}$

In New Zealand, intensity of review is most obvious in a number of different formulations of the reasonableness ground. ${ }^{70}$ Resorting to increased intensity of review based on a sliding scale or reliance on the intermediate category of unreasonableness is now commonplace in the High Court. Justice Wild's endorsement of the concept of the sliding scale of unreasonableness in Wolf $v$ Minister of Immigration has assumed particular currency, despite the remarks at High Court level not yet receiving direct endorsement at higher

67 See, for example, $R v$ Secretary of State for the Home Department, ex parte Bugdaycay [1987] AC 514 at 531 (HL); $R v$ Ministry of Defence, ex parte Smith [1996] QB 517 (CA); Brind, above n 25; $R$ v Lord Saville of Newdigate, ex parte A [2001] EWCA Civ 2048, [2000] 1 WLR 1855 [Lord Saville]; $R v$ Secretary of State for Education and Employment, ex parte Begbie [2000] 1 WLR 1115 at 1130; $R$ (Mahmood) v Secretary of State for the Home Department [2000] EWCA Civ 315, [2001] 1 WLR 840 at 849; $R$ (Asif Javed) v Secretary of State for the Home Department [2001] EWCA Civ 789, [2002] QB 129 at [49]; Sheffield City Council v Smart [2002] EWCA Civ 4 at [42]; Kennedy v Charity Commission [2014] UKSC 20, [2014] 2 WLR 808. See generally Tom Hickman Public Law After the Human Rights Act (Hart Publishing, Oxford, 2010) at 18 and 105 .

68 CUPE Local 963 v New Brunswick Liquor Corp [1979] 2 SCR 227; Canada (Director of Investigation \& Research) $v$ Southam Inc [1997] 1 SCR 748 and Pushpanathan $v$ Canada (Minister of Citizenship \& Immigration) [1998] 1 SCR 982; Baker v Canada (Minister of Citizenship and Immigration) [1999] 2 SCR 817. See also DP Jones and AS de Villars Principles of Administrative Law (5th ed, Carswell, Toronto, 2009) 489-522; Audrey Macklin "Standard of Review" in Colleen M Flood and Lorne Sossin (eds) Administrative Law in Context (Edmond Montgomery, Toronto, 2008) 197; David J Mullan "Deference: Is it Useful Outside Canada?" (2006) AJ 42 at 48-50; Michael Taggart "Outside Canadian Administrative Law" (1996) 46 UTLJ 649 at 649-650; Paul Daly A Theory of Deference in Administrative Law (Cambridge University Press, Cambridge, 2012) at 15-16.

69 Dunsmuir v New Brunswick 2008 SCC 9, [2008] 1 SCR 190 [Dunsmuir]. See generally n 86 below.

70 See generally Dean R Knight “A Murky Methodology” (2008) 6 NZJPIL 117; Knight, above n 2; Taggart, above n 15. 
levels. ${ }^{71}$ After canvassing domestic and overseas authority, he said "the time has come to state - or really to clarify" that the tests for unreasonableness expressed in CCSU and its local equivalent, Woolworths, "are not, or should no longer be, the invariable or universal tests of "unreasonableness" applied in New Zealand public law". ${ }^{72}$ Instead, Wild J commended an intermediate standard of simple unreasonableness, with the selection of the appropriate form depending on context. ${ }^{73}$ Other courts have also referred to or applied similar increased intensity of review under the reasonableness ground, adopting a variety of labels: "hard look" or "anxious scrutiny", "sliding scale", or Wild J's intermediate standard of reasonableness. ${ }^{74}$

As indicated above, appellate courts have so far been more coy about variegated unreasonableness. The Court of Appeal has occasionally remarked that unreasonableness must be treated as a contextual concept, something that inevitably varies with the circumstances. ${ }^{75}$ The Supreme Court has not directly addressed common law unreasonableness; the indications are that, on the one hand, the Court will readily accept that unreasonableness is contextual but, on the other hand, will be sceptical about attempts to structure that contextualism under rubrics like anxious scrutiny or sliding scales of intensity. ${ }^{76}$

\section{Contextual review}

Contextual review resists categorical approaches to judicial supervision. The strong refrain about context and its importance signals an emergent trend towards this open-textured and discretionary style of judicial supervision.

71 Wolf v Minister of Immigration [2004] NZAR 414 (HC) [Wolf]. See also Baragwanath J's articulation of multi-layered expressions of unreasonableness and substantive review: Ports of Auckland Ltd v Auckland CC [1999] 1 NZLR 601 (HC); Tupou v Removal Review Authority [2001] NZAR 696 (HC); Progressive Enterprises v North Shore City Council [2006] NZRMA 72 (HC); Mihos v Attorney-General [2008] NZAR 177 (HC).

72 Wolf, above n 71, at [47]; referring to CCSU, above n 21; and Woolworths, above n 36.

73 Wolf, above n 71, at [43].

74 See, for example, Pharmaceutical Management Agency Ltd v Roussel Uclaf Australia Pty Ltd [1998] NZAR 58 (CA) [Pharmac] at 66 ("hard look"); Pring, above n 35; B $v$ Commissioner of Inland Revenue [2004] 2 NZLR 86 (HC); Huang Xiao Qiong $v$ Minister of Immigration [2007] NZAR 163 (HC); Wright v Attorney-General [2006] NZAR 66 (HC); Sv Chief Executive of the Department of Labour [2006] NZAR 234 (HC); Dunne v CanWest TVWorks Ltd [2005] NZAR 577 (HC).

75 See, for example, Lovelock, above n 56; Pharmac, above n 74; Pring, above n 35; Discount Brands Ltd v Northcote Mainstreet Inc [2004] 3 NZLR 619 (CA); Conley v Hamilton City Council [2007] NZCA 543, [2008] 1 NZLR 789 (CA).

76 Knight, above n 2. 
This form of unstructured normativism, where the judges assess the circumstances in the round without any doctrinal scaffolding to control the depth of scrutiny, finds some favour in some parts of Anglo-Commonwealth administrative law. In its strong form, it suggests judicial instinct and discretionary judgement is, and should be, the essential litmus test for judicial intervention. In its weaker form, it captures doctrinal frameworks which are so open-textured that their essential feature is an overall evaluative judgement on the part of the judiciary. Normative reasoning and judgement is preferred over doctrinal reasoning. Joseph characterises the method in the following way: ${ }^{77}$

The forensic exercise is "inherently discretionary" and cannot be reduced to formulaic rules for producing predictable and mechanical outcomes. ... "Has something gone wrong?" is the litmus test for determining which cases are deserving of the court's intervention, and which cases are not.

While not prominently featuring in de Smith's textbook, its character is recognisable from a few passages in the later editions, particularly in relation to the deployment of "open-textured" standards or grounds, ${ }^{78}$ including the rubric of "abuse of power", ${ }^{79}$ and the non-doctrinal approach to deference in human rights adjudication. ${ }^{80}$ The content of the values may not, the authors say, be defined with precision and "will always need to be accompanied by a recognition of the particular circumstances of a special case". ${ }^{81}$ The circumstances which colour these standards are listed as "the breadth of the power conferred upon the decision-maker; the conditions of its exercise; the availability of alternative procedural protections, and the fairness to the parties involved (and to others affected by the decision)". 82

The emblematic case for the strong form of contextual review is the English case of $R v$ Panel on Take-overs and Mergers, ex parte Guinness plc. ${ }^{83}$ Lord Donaldson spoke of the courts stepping in when "something had gone wrong of a nature and degree which required the intervention of the

77 Philip A Joseph "Exploratory Questions in Administrative Law “ (2012) 25 NZULR 73 at 75,79 .

78 De Smith, above n 4, (6th ed) at [1-023]; (7th ed) at [11-029].

79 De Smith, above n 4, (6th ed) at [11-011], [11-087]; (7th ed) at [11-011], [11-089].

80 De Smith, above $\mathrm{n}$ 4, (6th ed) at [11-079]; (7th ed) at [11-088], referring especially to Huang, above $\mathrm{n} 51$.

81 De Smith, above n 4, (6th ed) at [11-023]; (7th ed) at [11-029].

82 De Smith, above n 4, (6th ed) at [11-023]; (7th ed) at [11-029].

$83 R v$ Panel on Take-overs and Mergers, Ex parte Guinness plc [1990] 1 QB 146 (CA) [Guinness]. Its subsequent application in England is rare. See also $R v$ National Lottery Commission, ex parte Camelot Group plc [2000] EWHC Admin 391, [2001] EMLR 3. For cases in which it was acknowledged but not made out see, for example, $R$ (Niazi) $v$ 
court" ${ }^{84}$ In its weaker form, unstructured contextualism is also represented by the English/British courts' current preference for non-doctrinal deference in human rights adjudication under the Human Rights Act 1998 (UK): ${ }^{85}$

The giving of weight to factors ... is the performance of the ordinary judicial task of weighing up the competing considerations on each side and according appropriate weight to the judgment of a person with responsibility for a given subject-matter and access to special sources of knowledge and advice. That is how any rational judicial decision-maker is likely to proceed.

Weak form instinctive review is also seen nowadays in one aspect of Canada's standards of review regime. In particular, following the collapse of the different forms of unreasonableness, the new broad-church formulation of unreasonableness presents a more discretionary and open-textured approach. ${ }^{86}$

Secretary of State for the Home Department [2007] EWHC 1495; Lord Saville, above n 67. Compare the "innominate ground" (above).

84 Guinness, above n 83, at 160. I have distinguished the Guinness approach from variegated forms of unreasonableness because the Guinness approach has a broader ambit and more general character, unlike the forms of unreasonableness which try to express particularised degrees of scrutiny.

85 Huang, above n 51, at [16]. This preference for non-doctrinal deference and weight has been reinforced subsequently by the House of Lords and Supreme Court in a number of cases. See, for example, $R$ (SB) v Governors of Denbigh High School [2006] UKHL 15, [2007] 1 AC 100 (HL); Belfast City Council v Miss Behavin'Ltd [2007] UKHL 19, [2007] 1 WLR 1420; $R$ (Animal Defenders International) v Secretary of State for Culture, Media and Sport [2008] UKHL 15, [2008] 1 AC 1312 at [33] (and, in that context, "great weight"); R (Quila) v Secretary of State for the Home Department [2011] UKSC 45, [2012] 1 AC 621; R (Nicklinson) v Ministry of Justice [2014] UKSC 38, [2014] 3 WLR 200 at [166]-[171], [348]; $R$ (Lord Carlile) v Secretary of State for the Home Department [2014] UKSC 60, [2015] AC 945. See also Kennedy v Charity Commission [2014] UKSC 2, [2015] AC 455 at [51] (correctness review, along with an emphasis on "weight", in the context of common law unreasonableness review).

86 Dunsmuir, above n 69. See generally Paul Daly "The Struggle for Deference in Canada" in Hanna Wilberg and Mark Elliott (eds) The Scope and Intensity of Substantive Review (Hart, Oxford, 2015) 297; Paul Daly “Dunsmuir's Flaws Exposed: Recent Decisions on Standard of Review" (2012) 58 McGill LJ 483; David J Mullan "Dunsmuir v. New Brunswick, Standard of Review and Procedural Fairness for Public Servants: Let's Try Again!” (2008) 21 CJALP 117; Gerald P Heckman "Substantive Review in Appellate Courts Since Dunsmuir" (2009) 47 Osgoode Hall LJ 751; Andrew Green "Can There Be Too Much Context in Administrative Law? Setting the Standards in Canadian Administrative Law" (2014) 47 UBC L Rev 443. 
Within New Zealand's legal system, one finds a strong undercurrent of support for broadly framed and unconstrained supervisory review. This is undoubtedly attributable to the significance of Lord Cooke and his simplicity project. ${ }^{87}$ The preference for simplicity over complexity, substance over form, and discretion over structure continues to have a degree of currency today. Over many decades Lord Cooke promoted a model of judicial review that was shorn of formalism and technicalities; instead he encouraged the notion that judges ought to retain the broad power to intervene to address injustice wherever it was seen. ${ }^{88}$ Emblematic of his style, of course, was his strong advocacy for the recognition of "substantive fairness" as a legitimate ground of judicial review, "shading into but not identical with unreasonableness" ${ }^{89}$ Substantive fairness allows judges, he said, to consider "the adequacy of the administrative consideration given to a matter and of the administrative reasoning" and enables "a measure of flexibility enabling redress for misuses of administrative authority which might otherwise go unchecked". ${ }^{90}$ Consistent with this theme, he also signalled his support for Lord Donaldson's analogous "innominate" ground of review. ${ }^{91}$

87 Dean R Knight “Simple, Fair, Discretionary Administrative Law” (2008) 39 VUWLR at 99; Michael Taggart "The Contribution of Lord Cooke to Scope of Review Doctrine in Administrative Law: A Comparative Common Law Perspective" in Paul Rishworth (ed) The Struggle for Simplicity in the Law (Butterworths, Wellington, 1997) 189; Janet McLean "Constitutional and Administrative Law: The Contribution of Lord Cooke" in Paul Rishworth (ed) The Struggle for Simplicity in the Law (Butterworths, Wellington, 1997) 221; Joseph, above n 12.

88 As well as promoting a simplified statement of the tripartite grounds, Lord Cooke criticised the language of jurisdiction and jurisdictional error (Bulk Gas Users Group Ltd v Attorney-General [1983] NZLR 129 (CA) at 136); formalist natural justice (Daganayasi, above n 55); narrowly defined standing (Environmental Defence Society Inc v South Pacific Aluminium Ltd (No 3) [1981] 1 NZLR 216 (CA)); and Wednesbury unreasonableness (International Traders' Ferry, above n 56, at 452; Daly, above n 51, at [32]).

89 Thames Valley, above n 52, at 652. See also Northern Roller Milling Co Ltd v Commerce Commission [1994] 2 NZLR 747 (HC). Despite Lord Cooke's efforts in the late 1980s and early 1990s, it failed to gain any real traction as a ground in itself; see Joseph, above $\mathrm{n} 12$, at 65 .

90 Thames Valley, above n 52, at 652, 653.

91 Robin Cooke "Fairness" (1989) 19 VUWLR 421 at 426; Lord Cooke of Thorndon "The Discretionary Heart of Administrative Law" in Christopher F Forsyth and Ivan Hare (eds) The Golden Metwand and the Crooked Cord (Clarendon Press, Oxford, 1998) 203 at 212; "Foreword" in GDS Taylor Judicial Review: A New Zealand Perspective (1st ed, Butterworths, 1991) v; "Foreword" in Philip A Joseph Constitutional and Administrative Law in New Zealand (2nd ed, Brookers, Wellington, 2001) vi; Robin Cooke "The Road Ahead for the Common Law" (2004) 53 ICLQ 273 at 284. 
Others have since continued this campaign in favour of broad and unconstrained supervisory review. A few examples demonstrate the continuing legacy. First, open-textured and discretion-laden judicial review doctrines continue to marshal strong support. Lord Cooke's substantive fairness has already been mentioned; although the drive for a ground of that name has since diminished, the campaign has shifted to other doctrines. ${ }^{92}$ Others have echoed his support for a simplified and unified form of unreasonableness. ${ }^{93}$ Similarly, the innominate ground from Guinness has been deployed, with the Court of Appeal recommending its "more flexible approach" when reviewing quasi-public decisions of unincorporated bodies.$^{94}$ This innominate ground therefore seems to have acquired greater currency in New Zealand than in England where it was first deployed. Secondly, amongst the senior judiciary, there is little appetite for structured formulations of deference, either in substantive review at common law ${ }^{95}$ or in human rights adjudication under the New Zealand Bill of Rights Act 1990. ${ }^{96}$

Finally, leading members of the academy and bar continue to crusade strongly in favour of simple and discretionary approaches to judicial supervision. For example, Professor Joseph speaks strongly against the "terminological congestion" and "pedagogical confusion" in judicial

92 See Knight, above n 2, at 424.

93 See, for example, Lovelock, above n 56, at 403 (Thomas J) ("whether a reasonable authority acting with fidelity to its empowering statute could have arrived at the decision it did in the circumstances of that case").

94 Cameron, above n 52, at 430. See also its recognition in Royal Australasian College of Surgeons v Phipps [1999] 3 NZLR 1 (CA); Health Authority Trust v Director of Health and Disability Consumer Advocacy [2008] NZCA 67, [2008] BCL 416; Wilkins $v$ Auckland District Court (1997) 10 PRNZ 395 (HC); Issac v Minister of Consumer Affairs [1990] 2 NZLR 606 (HC); Taiaroa, above n 55; Shaw v Attorney-General (No 2) [2003] NZAR 216 (HC); Te Runanga o Ngai Tahu v Attorney-General CIV-2003404-1113, 6 November 2003.

95 See, for example, Ye v Minister of Immigration Transcript SC 53/2008, 21-23 April 2009 at 179 (Elias CJ) (deference described as "dreadful"), quoted in Knight, above n 2, at 400; Austin, Nichols \& Co Inc v Stichting Lodestar [2007] NZSC 103, [2008] 2 NZLR 141; McGrath v Accident Compensation Corporation [2011] NZSC 77, [2011] 3 NZLR 733; Sian Elias “Administrative Law for 'Living People"” (2009) 68 CLJ 47 at 65 ("there is no need for any amplification of reasonableness or fairness as both [take] their shape from context”). For a more detailed analysis see Knight, above n 2. See also Andrew Beck "Farewell to the Forum Otiosum?" [2011] NZLJ 269 and Edward Willis "Judicial Review and Deference" [2011] NZLJ 283.

96 In the leading decision on assessment of justified limitations under the New Zealand Bill of Rights Act 1990, judges only made passing reference to any influence deference should have and, when mentioned, it was characterised as a general form of latitude, which may vary in the circumstances: $R v$ Hansen, above $n 54$, especially at [111] (Tipping J) and [268] (Anderson J). 
review. ${ }^{97}$ Part of his solution is exposing the "instinctual impulse" as the chemistry of the judicial task. ${ }^{98}$ Leading silk Francis Cooke applauds Joseph's rationalisation, ${ }^{99}$ as well as speaking about the importance of simplicity: "Notions of intensity simply obscure the real task, which is to ensure the law is being followed." 100

\section{Principles for Evaluating the Schemata}

The various schemata modulating the depth of scrutiny exhibit both commonality and individuality. On the one hand, all the schemata enable significant variability in the supervisory task. On the other hand, the manner in which each schema expresses this variability differs. Isolating the former allows us to focus the normative assessment on the efficacy of the latter; the principal concern is with the manner by which the depth of scrutiny is modulated, not the fact of modulation per se. The acceptance that judicial review is variable in nature allows us to turn our attention to the way the modulation takes place. ${ }^{101}$

How then do we assess the merits of the manner of modulation? Some measure is needed to guide the assessment. It is insufficient to merely assert that one means is, for example, more "robust" than others, without dissecting why that is so. ${ }^{102}$

Here, I explore how we might usefully employ Fuller's principles of legality and efficacy as one way of evaluating the strengths and weaknesses of the different schemata. One perspective, and the one I adopt here, is to treat the schemata as rule-regimes which regulate the exercise of power and discretion of judges in the supervisory jurisdiction. In other words,

97 Joseph, above n 77 , at 81 .

98 At $74,101$.

99 Francis Cooke "The Future of Public Law in New Zealand: a tale of two elephants" in Administrative Law - the public law scene in 2011 (New Zealand Law Society, Wellington, 2011) 75.

100 Francis Cooke “A Personal Word” (2008) 39 VUWLR 15 at 19, echoing the sentiments of his judge father.

101 For others squarely recognising the ubiquity of variability in judicial review see, for example, Taggart, above n 15, at 450; DGT Williams "Justiciability and the Control of Discretionary Power" in Michael Taggart (ed) Judicial Review of Administrative Action in the 1980s - Problems and Prospects (Oxford University Press, Auckland, 1986) 103 at 106 ; Joseph, above $\mathrm{n} 77$, at 75 .

102 See, for example, Daly, above n 86. Daly makes this claim a number of times; speaking to his normative preference for "doctrinal", not "epistemic", deference. However, the orientation of his project is more towards the drivers of deference, rather than the means by which it is manifest. 
judicial review of administrative decision-making is not merely the judicial supervision of the application of rules by the administration but also involves the creation and deployment of rules about the exercise of judicial power. Judges are agents of public power too.

Viewed in this way, we can then draw on rule of law scholarship addressing the appropriateness and efficacy of rule-regimes in order to assess the merits of the different schemata. Fuller's principles of legality are well regarded as a set of standards for examining rule-based systems for their value and virtue. ${ }^{103}$ Fuller identified eight criteria. ${ }^{104}$ First, laws ought to be general, in the sense that there must be rules of some kind. Secondly, laws ought to be promulgated and publicly accessible. Thirdly, laws should be prospective. Fourthly, laws should be clear. Fifthly, laws should be relatively stable. Sixthly, laws should be non-contradictory. Seventhly, laws should not require the impossible. Finally, there should be congruence between law and official action applying that law. To that I have added one further criterion, hortatory versatility, to also recognise the wide functions of judicial review in administrative law.

The focus here is on the efficacy of the modulation of the depth of scrutiny, as one way to assess the normative value of the schemata. It assumes that the judicial methodology in the supervisory jurisdiction has a rule-based character, which therefore justifies a rule of law style of analysis. Others may emphasise the achievement of administrative justice, through whatever means, as a measure of the normative value of each schema. However, a Fullerian normative approach does not prejudge that evaluation. Rather, the assessment assumes that the ubiquity of variability throughout the different schemata supports the goals of administrative justice. The fact that the supervisory jurisdiction is a check or review function does not prevent scrutiny of its internal morality and how it explicates methodological rules. While I am not unconcerned with the delivery of administrative justice (however that is to be defined), I say that the achievement of that ultimate objective is left open by the different schemata because of the inherent variability of, and discretion that imbues, them all.

103 Fuller, above n 6. Fuller's criteria have been echoed by a number of others writing on the rule of law. See, for example, Joseph Raz "The Rule of Law and its Virtue" (1977) 93 LQR 195; Tom Bingham The Rule of Law (Penguin, London, 2011).

104 There has been some debate about their jurisprudential quality (expressions of morality or otherwise), but this characterisation is not important for present purposes; the value of the criteria lies in the expression of these qualities as standards against which to evaluate rules and regimes. See, for example, Fuller, above n 6, at 53, 204; Raz, above n 103, at 226; Martin Loughlin Foundations of Public Law (Oxford University Press, Oxford, 2010) at 334. 
I return now to the criteria themselves. I explain the nature of Fuller's concerns and suggest how each principle might assist when assessing methodologies in the supervisory jurisdiction. As will be apparent, the criteria tend to overlap at times and sometimes converge. Further, it is important to note that these criteria are aspirational in character; even Fuller did not characterise them as absolute duties. ${ }^{105}$ They are useful, though, in exposing lines of analysis. Inevitably there are trade-offs that must be made between the different criteria when evaluating schemata for normative purposes. The criteria are intended to help guide that assessment and to illuminate the tradeoffs that are involved. In the context of this article, the purpose is to give a flavour of the style of analysis only. A complete normative analysis of the different schemata is a much bigger endeavour and beyond the scope of this article. The aim here is to foreshadow the criteria and nature of analysis only.

\section{A Generality}

Fuller's explanation of generality focuses on the need for rules. "General declarations" of rules are preferred over other forms of commanding compliance. ${ }^{106}$ The faithful application of previously declared rules combining the idea of generality with congruence - is an essential feature of social ordering through law; a functioning legal order demands "the existence of a relatively stable reciprocity of expectations between lawgiver and subject". ${ }^{107}$ Fuller recognises the preference for rules is only aspirational; he speaks of a "struggle" between "broad freedom of action" and declared general rules. ${ }^{108}$ This recognises an important trade-off when assessing generality: between flexibility and responsiveness on the one hand, and consistency and predictability on the other. ${ }^{109}$

In the context of the different schemata, for example, contextual review would perform poorly because it repudiates any need for rules or law, in favour of the judicial instinct. The scope of review schemata would, on its face, perform well under this principle due to the way in which defined categories (viz rules) condition the supervision task; but there remains a danger that the doctrinal rules merely camouflage judicial discretion because

105 Fuller, above n 6 , at 43 . The only one he marks out as essential is promulgation (public accessibility of law to those affected).

106 At 210.

107 At 209.

108 At 213.

109 On equality and consistency see Fuller, above n 6, at 211. See also John Rawls $A$ Theory of Justice (Belknap, Cambridge (Mass), 1971); Karen Steyn “Consistency” (1997) 2 JR 22; Jeffrey Jowell “Is Equality a Constitutional Principle?” (1994) 47 CLR 1. 
of their undue complexity, conceptual dissonance and ease by which they are manipulated.

\section{B Public accessibility}

The virtue of public accessibility has a number of aspects. First, from an instrumental perspective, openness helps expose the legal regime and power exercised to scrutiny and critique. ${ }^{110}$ Secondly, the promulgation of publicly accessible rules is an essential ingredient to understanding a legal regime (viz clarity) and being able to predict the outcome of cases. ${ }^{111}$ Thirdly, public promulgation has a non-instrumental aspect in the way it enhances the legitimacy and "basic integrity" of the legal regime. ${ }^{112}$ Rule-making and rule-application are both undertaken by the courts when exercising their supervisory jurisdiction and are inevitably intertwined; furthermore, judicial discretion assumes a powerful role. Thus it is also necessary under this criterion to be attentive to transparency in the judicial reasoning process. Fuller highlighted the importance of reason-giving as an aspect of accessibility (and clarity); it is properly taken for granted, he says, that the courts "must explain and justify their decisions, [and] that they must demonstrate that the rules they apply are 'grounded in principle"". ${ }^{113}$

In relation to the different schemata, this criterion values the public articulation of principles or rules governing the courts' supervisory jurisdiction, along with the reasoned elaboration of the basis on which those principles or rules are applied in particular cases. This is consistent with the "culture of justification" which the courts tend to expect from administrative decision-makers nowadays. ${ }^{114}$ This principle is generally

110 Fuller, above n 6, at 51.

111 At 50.

112 At 212, 214, 222.

113 Lon L Fuller Anatomy of Law (Frederick A Praeger, London, 1968) at 91. See also John Rawls "The Law of Peoples" (2001) 20 Critical Inquiry 36; Jon Elster "Deliberation and Constitution Making" in Jon Elster (ed) Deliberative Democracy (Cambridge University Press, Cambridge, 1998) 97 at 111 ("the civilizing force of hypocrisy"); Francisco J Urbina “A Critique of Proportionality” (2012) 57 Am J Juris 49 at 66, drawing on Mattias Kumm "The Idea of Socratic Contestation and the Right to Justification" (2010) 4 Law and Ethics of Human Rights 147 (by demanding justification, "Socratic contestation ... increase[s] rationality").

114 Etienne Mureinik “A Bridge to Where?” (1994) 10 SAJHR 31 at 32; David Dyzenhaus "Law as Justification" (1998) 14 SAJHR 11; Taggart, above n 15, at 461. On reasongiving see generally PP Craig "The Common Law, Reasons and Administrative Justice" [1994] CLJ 282; AP Le Sueur "Legal Duties to Give Reasons" (1999) 52 CLP 150; Mark Elliott "Has the Common Law Duty to Give Reasons Come of Age Yet?" [2011] PL 56. 
enhanced by those schemata which favour the expression of rules, but is also concerned to ensure that any judicial discretion created by those rules is explicitly and transparently reasoned. Thus, concerns would arise from the indirect, categorical and sometimes conclusory approaches found in scope and grounds of review, while the transparent and structured reasoning associated with intensity of review is to be valued.

\section{Prospectivity}

A retroactive law is, in Fuller's account, a "monstrosity" — objectionable in terms of both morality and efficacy; thus prospectivity is seen as an important virtue. ${ }^{115}$ However, Fuller was also prepared to admit that, in the context of a system of generally prospective laws, laws with retroactive effect may in some circumstances be tolerable. ${ }^{116}$ Notably, he acknowledged that judicial adjudication of disputes inevitably has some retroactive effect, so deeper analysis is required to parse and condemn any retroactivity. ${ }^{117}$

In the context of the different schemata, with a focus on regime design, retrospectivity in the pure sense does not arise; however, we should be alert to any retrospective effect arising from the application of the rules with each schema. ${ }^{118}$ This concern is consistent with the courts' concern for legal certainty in administrative decision-making. ${ }^{119}$ As with the principle of generality, schemata based around rules - and rules which seek to minimise covert judicial discretion - generally measure up well against this principle; those like contextual review which replace doctrinal rules with naked judicial discretion score poorly.

115 Fuller, above n 6, at 53.

116 At 53.

117 At 56. See also Fuller, above n 113, at 100.

118 Fuller, above n 113, at 101.

119 See, for example, the treatment of legitimate expectations (Coughlan, above n 51; In re Preston [1985] 1 AC 835 (HL)) and vagueness (Black-Clawson International Ltd v Papierwerke Attorney-General [1975] AC 591 (HL); R v Misra [2004] EWCA Crim 2375, [2005] 1 Cr App R 21). See generally Robert Thomas Legitimate Expectations and Proportionality in Administrative Law (Hart, Oxford, 2000); Søren J Schønberg Legitimate Expectations in Administrative Law (Oxford University Press, Oxford, 2000); Timothy AO Endicott Vagueness in Law (Oxford University Press, Oxford, 2000). 


\section{Clarity}

Clarity is described by Fuller as "one of the most essential ingredients of legality". ${ }^{120}$ This criterion condemns vagueness and obscurity in legal rules. ${ }^{121}$ Much of the underlying rationale for this principle is legal certainty. Laws should be clear in meaning so that they are capable of being obeyed and in order to allow people to live their lives conscious of the legal consequences that may flow from their actions. ${ }^{122}$ Thus, this principle factors in concerns about predictability within the legal regime. Fuller is also concerned that lack of clarity - regimes that are vague, indefinite and favour governmental discretion - may "rob" the regimes of their legitimacy. ${ }^{123}$

Applied to the different schemata, this criterion addresses how clearly the principles governing the deployment of the courts' supervisory jurisdiction are expressed, whether they are understandable, and whether they unduly rely on standards which are vague or indeterminate. Thus, the scope of review schema scores poorly due to its complexity and manipulability. So too does contextual review; while employing a seemingly simple litmus test, the vagueness of the instinctual standards which are deployed undermine clarity.

\section{E Stability}

Stability, in the sense employed by Fuller, requires that laws not change too frequently. ${ }^{124}$ The objection, like for retrospective rules, is that instability makes laws unpredictable and difficult to comply with. Hence, there is a degree of overlap between this criterion and the criteria looking at clarity, prospectivity and non-impossibility; they all address the predictability of laws and the ability to comply with them. As the different legal regimes and methodologies have been isolated, the focus under this criterion is the treatment of change and evolution within each schema, rather than changes from one schema to another. For example, developments in judicial

120 Fuller, above n 6, at 63 .

121 At 63, 212, 213.

122 At 209, 212. See also Friedrich von Hayek The Road to Serfdom (University of Chicago Press, Chicago, 1944); Joseph Raz The Authority of Law (Clarendon, Oxford, 1979); Jeremy Waldron The Law (Routledge, London, 1990); Max Weber Wirtschaft und Gesellschaft: Grundriß der Verstehenden Soziologie (1921) (translated ed: Guenther Roth and Claus Wittich (eds) Economy and Society: an outline of interpretive sociology (University of California Press, Berkeley, 1978)) ("legal guaranty"); Jürgen Habermas Between Facts and Norms (MIT Press, Cambridge (Mass), 1996).

123 Fuller, above n 6, at 212.

124 Fuller, above n 6, at 79 . 
supervision and changing preferences can be readily accommodated within the generalised and contextual approaches mandated under the intensity of review and contextual review schemata; changes to the supervisory method under the scope - and, to a lesser degree, grounds - of review schemata regime involve the revision of the supervisory frameworks.

\section{F Non-contradiction}

The focus of non-contradiction - and the related notion of coherence is the schematic unity of the system and the extent to which it is bound together by principle. ${ }^{125}$ Coherence contrasts law as a seamless web with law as a patchwork quilt, with the former being valued. Although consistent treatment is a key aspect of coherence, coherence also raises broader questions about the meta-architecture of a schema, that is, its organising theory or manner in which it is systematised. The focus extends to matters such as its comprehensiveness, connectedness and internal unity. ${ }^{126}$ Fuller commends coherence, not just in rule-making but in rule-application too. This he describes as a "problem of system", where the "rules applied to the decision of individual controversies cannot simply be isolated exercises of judicial wisdom"; even when deployed, they must maintain "some systemic interrelationship" and display "some coherent internal structure". ${ }^{127}$ Coherence and non-contradiction are enhanced by "principles that transcend their immediate application" and "bind the elements of law into a coherent system of thought". ${ }^{128}$

The grounds of review schema was, for example, developed in order to improve on scope of review's lack of coherence; however, reliance on classification in circumstances of overlap and the role of contingent and emergent grounds complicate this simplicity and add a gloss of uncertainty. Intensity of review and contextual review, in contrast, both offer more holistic and overarching approaches to the determination of the depth of scrutiny, thus presenting more generalised and coherent regimes; but the

125 See also Ronald Dworkin Law's Empire (Belknap Press, Cambridge (Mass), 1988) at 134, 167 ("integrity"); and Neil MacCormick Rhetoric and The Rule of Law (Oxford University Press, Oxford, 2005) at 189-193 ("normative coherence" is a "commonly accepted criterion" of the soundness of judicial rulings; legal norms "should be rationally related as a set, instrumentally or intrinsically, to the realization of some common value or values" or as "fulfilling some more or less clearly articulated common principle or principles").

126 Ken Kress “Coherence and Formalism” (1993) 16 Harv J L \& Pub Policy 639.

127 Fuller, above n 113, at 94.

128 At 94. 
application of and outcomes from both are less certain, less predictable and, to some degree, inconsistent.

\section{G Non-impossibility}

In Fuller's original account, non-impossibility is focused on the (in)ability to achieve compliance with rules. In other words, concern is expressed about standards set by rules that are unachievable. While this principle has virtue, its concern does not directly arise in this context, because the rules and methodology deployed by judges are self-created and judges are unlikely to fashion totally unachievable rules to regulate their own behaviour. However, the gist of this principle is the practicality of compliance. Indeed, Fuller also expresses this principle in terms of the "possib[ility] of execution"; ${ }^{129}$ further he acknowledges that "no hard and fast line" could be drawn and the virtue was more a question of degree. ${ }^{130}$

In this context, this principle therefore speaks more to the practicality of the different schemata. In particular, this criterion looks at their effect on the litigation and supervision process. It is attentive to any procedural consequences and how the schemata might affect advocacy and deliberation in judicial review hearings and decisions. For example, the open-textured nature of contextual review provides little substantive guidance about the appropriate depth of scrutiny, making it more difficult to predict the nature of the evidence, forensic analysis and argument. In contrast, grounds of review provides some forensic simplicity, at least when argumentation takes place on the territory of the traditional grounds of review; litigants can be relatively confident on the nature of the argument and the associated nature of evidence required.

\section{H Congruence}

Congruence insists that official action is faithful to declared rules. ${ }^{131}$ This criterion seeks to bind the other criteria with a focus on operation and implementation. Fuller is quick to rebut the idea that the merger of lawmaker and law-applier, as is the case with judicial review, necessarily brings congruence. First, the nature of the judicial hierarchy means congruence may still be impaired because the making of law by judges is always subject to 
higher court (dis)approval. Secondly, there remains room for dissonance between the declaration and application of law, even by the same actor. ${ }^{132}$

In the context of evaluating the different judicial review schemata, this principle allows us to examine the fidelity between the rule-regime expressed by judges and applied by judges. This aspiration for congruence, fidelity and candour is based on the same impulse that has driven the courts to develop similar expectations of administrative decision-makers. The courts expect administrators to faithfully apply the law. This principle expects the same of the judges.

Scope of review, for example, performs poorly, with its complexity and conceptual dissonance, encouraging latent manipulation of the critical distinctions which determine the depth of review. The more circumstantial intensity of review and contextual review schemata provide greater judicial flexibility and seek to incorporate more explicitly the key drivers underlying the judicial decision to intervene or not, thus supporting congruence in application.

\section{Hortatory versatility}

The final criterion - hortatory versatility - is not found in Fuller's account but is an important dimension of judicial review. While judicial review's immediate role is the policing of administrative legality, it also has an important collateral role in articulating and elaborating the principles of good administration that ministers, public bodies and officials ought to honour. These principles of good administration have currency both within and beyond the system of judicial review itself — described by Harlow and Rawlings as its "hortatory function". ${ }^{133}$ While our predominant concern here

132 At 82 ("the tune called may be quite undanceable by anyone, including the tune-caller"). King echoes this concern, when he worries about the gap between "what judges say and do": Jeff King "Proportionality: A Halfway House" [2010] NZ L Rev 327 at 334.

133 Harlow and Rawlings, above n 19, at 669. Harlow and Rawlings say the goal of the hortatory or educative function is "ultimately the internalising by administrators of legal values" (at 728). The establishment of general principles for the proper exercise of discretion helps promote good decision-making on a prophylactic basis ("firewatching") rather than merely addressing deficiencies after the fact ("fire-fighting") (at 728). See also David Feldman "Judicial Review: A Way of Controlling Government?" (1988) 66 Pub Admin 21 (role of law in structuring, not just directing and limiting, discretion); Simon Halliday Judicial Review and Compliance with Administrative Law (Hart, Oxford, 2004) at 15 (judicial review's messaging role and the way general principles influence bureaucratic values and decision-making); Marc Hartogh and Simon Halliday (eds) Judicial Review and Bureaucratic Impact (Cambridge University Press, Cambridge, 2004). 
is the system of judicial review itself, the utility of the principles of review beyond the system and in administrative law generally should not be ignored when evaluating different schema.

Thus, those schemata generating complex and confusing sets of rules (for example, scope of review) or generating no rules as all (for example, contextual review) generally perform poorly against this criterion. In contrast, grounds of review performs well: the simplified and generalised approach means it usefully expresses administrative norms suitable for domains beyond judicial review - a practice which has helped embed it as the dominant framework in New Zealand.

\section{Conclusion}

In this article, I have framed a number of schemata to help isolate the key methodologies within New Zealand and Anglo-Commonwealth administrative law to modulate the depth of review. These schemata described as scope, grounds, intensity and context - represent generalised and distinct ways in which the mediation between judicial vigilance and restraint is manifest. Drawn from the changing language of de Smith's famous textbook on judicial review, the different schemata provide a basis on which we can assess the efficacy and virtue of different ways to modulate the depth of scrutiny.

For this purpose I have suggested that Fuller's principles of legality generality, public accessibility, prospectivity, clarity, non-contradiction, nonimpossibility, stability and congruence - along with hortatory versatility, provide a useful template for this normative task. Treating the schemata as rule-regimes which regulate the exercise of power and discretion of judges in the supervisory jurisdiction, Fuller's rule of law principles allow us to isolate the different strengths and weaknesses of the manner by which the depth of scrutiny is modulated in judicial review cases.

While the detailed evaluation of each schema is left for another day, these benchmarks provide a means to assess the efficacy and virtue of the schemata. And, hopefully, the analysis of the schemata in this way will enrich our conversations about the modulation of the depth of scrutiny and enable us to better embrace the inherent variability of judicial review. 